OSOBA I SAMOTNOŚĆ. MIĘDZY CODZIENNOŚCIĄ A MISTYKA

Filozofia Chrześcijańska • Tom 12, Poznań 2015

Uniwersytet im. Adama Mickiemicza w Poznaniu • Wydział Teologiczny

doi: $10.14746 /$ fc.2015.12.01

PIOTR DOMERACKI

Uniwersytet Mikołaja Kopernika w Toruniu

\title{
Paradygmatyczne konceptualizacje samotności i wspólnotowości w dyskursie monoseologicznym
}

The Paradigmatic Conceptualizations of Loneliness and Communitiveness in a Monoseological Discourse

Musimy jednak mieszać i wzajemnie przeplatać dwie rzeczy: samotność i obcowanie z ludźmi*.

Samotność zawsze zakłada potrzebę wspólnoty, tęsknotę za wspólnotą**.

\section{VITA SEPARATA: DYSONANS SAMOTNOŚCI I WSPÓLNOTOWOŚCI}

W ramach rozmaitych szkół, nurtów, kierunków, koncepcji i stanowisk, w ciagu dziejów trwania i rozwoju filozofii zachodniej ukształtował się, choć stosunkowo późno wyodrębnił dyskurs, który z grecka nazywam monoseologicznym ${ }^{1}$, a który składa się na filozofię samotności i ją tworzy. Określona tak została dopiero w wieku XX, niezależnie od siebie, przez Mikołaja Bierdiajewa i Emmanuela Levinasa (którzy jako pierwsi posłużyli się tym wyrażeniem). Differentia specifica dyskursu monoseologicznego jest, jak wskazuje nazwa, tematyzacja i artykulacja fenomenu

* L.A. Seneka, O pokoju ducha, w: tenże, Dialogi, tłum. L. Joachimowicz, Warszawa 1989, XVII 3, s. 661-662; wyd. z 1963, s. 541.

** M. Bierdiajew, Rozważania o egzystencji. Filozofia samotności i wspólnoty, thum. H. Paprocki, Kęty 2002, s. 54.

${ }^{1}$ Termin 'monoseologia' wywodzę z języka starogreckiego od słów monosé - 'samotność' i logos - 'nauka'. Nazwą tą oznaczam w ogólności wszystkie dyscypliny naukowe zainteresowane analizowaniem oraz prowadzeniem systematycznych badań nad samotnością w trybie interdyscyplinarnym. Węziej przez monoseologię rozumiem samą tylko 'filozofię samotności', a oba wyrażenia traktuję jako synonimy. 
samotności w aspekcie ontologicznej, funkcjonalnej i znaczeniowej „gęstości” (mówiąc po Ricoeurowsku²) rzeczywistości, jaką stanowi.

Problematyka monoseologiczna rozciaga się, rzecz jasna, poza obszar samej tylko filozofii na wielorakie dyscypliny wiedzy ${ }^{3}$. W ostatnich latach, także poza nauką, przeżywa ona dynamiczny rozkwit. Świadczy o tym chociażby znaczna i stale rosnąca liczba wydawnictw, od periodyków ${ }^{4}$ (szczególnie popularnonaukowych i opiniotwórczych) poczynając, na poważnych rozprawach naukowych kończąc ${ }^{5}$.

Własnym torem niejako, w ostatnich latach coraz bardziej ekspansywnie, rozwija się myśl problematyzująca zagadnienie wspólnoty i dążeń wspólnototwórczych, które określam mianem „wspólnotowości”. W wieku XX można wręcz mówić o eksplozji zainteresowania tymi fenomenami. Dość wspomnieć całe kierunki myślenia, takie jak: socjalizm, komunitaryzm, dyskursywizm, filozofię dialogu czy personalizm. Także w minionych latach obecnego wieku utrzymuje się tendencja do naukowego opracowywania zagadnienia wspólnotowości i wspólnoty ${ }^{6}$, coraz częściej manifestując się w pojedynczych, acz znaczących stanowiskach. Jako przykład przywołać tu należy co najmniej prace: Helmutha Plessnera ${ }^{7}$ (Granice wspólnoty) oraz Zygmunta Baumana ${ }^{8}$ (Wspólnota).

Jeśli chodzi o rangę ważności, to choć problematyka samotnościowa, poczynając od drugiej połowy XX stulecia, zaczynała zyskiwać na znaczeniu, stopniowo się autonomizując, mimo to jednak, co zrozumiałe, nie zdołała osiagnąć po-

${ }^{2}$ P. Ricoeur, Hermeneutyczna funkcja dystansu, w: tenże, Język, tekst, interpretacja. Wybór pism, thum. P. Graff i K. Rosner, Warszawa 1989, s. 224.

${ }^{3}$ Wśród nich przede wszystkim należy wymienić: psychologię, socjologię, pedagogikę, etnologię oraz teologię.

${ }^{4}$ Tytułem przykładu można tu wspomnieć chociażby: „Charaktery”, „Przegląd”, „Wysokie Obcasy Extra”, jezuicki „Szum z Nieba”.

${ }_{5}^{5}$ Por. B.L. Mijuskovic, Loneliness in Philosophy, Psychology, and Literature, Bloomington 2012; Z. Dołęga, Samotność młodzieży - analiza teoretyczna i studia empiryczne, Katowice 2003; E. Dubas, Edukacja dorostych w sytuacji samotności i osamotnienia, Łódź 2000; Przeciw samotności, red. J. Twardowska-Rajewska, Poznan 2005; Zrozumieć samotność. Studium interdyscyplinarne, red. P. Domeracki, W. Tyburski, Torun 2006; K. Dybeł, Samotność w literaturze średniowiecznej Francji. Literatura narracyjna XII-XIII wieku, Kraków 2009; Motywy samotności i wspólnoty $w$ dawnych literaturach romańskich (Średniowiecze - Oświecenie), red. D. Szeliga i E.D. Żółkiewska, Warszawa 2010; Samotność i osamotnienie, „Horyzonty Wychowania” 11, 2012 (22), Akademia Ignatianum w Krakowie; K. Sobstyl, Samotność i jej obrazy w języku, Lublin 2013; Singlizm. Nowy styl życia w ponowoczesnym świecie, red. K.L. Kuklińska, Warszawa 2013; S. Turkle, Samotni razem. Dlaczego oczekujemy więcej od zdobyczy techniki, a mniej od siebie nawzajem, thum. M. Cierpisz, Kraków 2013.

${ }^{6}$ Zob. Wspólnota komunikacyjna w teorii i praktyce, red. B. Sierocka, Wrocław 2007.

${ }^{7}$ Por. H. Plessner, Granice wspólnoty. Krytyka radykalizmu społecznego, thum. J. Merecki, Warszawa 2008.

${ }^{8} \mathrm{Z}$. Bauman, Wspólnota. W poszukiwaniu bezpieczeństwa w niepewnym świecie, thum. J. Margański, Kraków 2008. 
ziomu zainteresowania ani stopnia zaawansowania badań nad fenomenem wspólnotowości, a tym bardziej go pod tym względem prześcignąć. Wielu autorów wskazuje i podkreśla centralna, dominująca pozycję tego zagadnienia nie tylko na terenie filozofii, ale całej w ogóle humanistyki i nauk społecznych. Niektórzy mówią wręcz o obsesji wspólnotowości. Tak, na przykład, Plessner bezceremonialnie stwierdza, że wspólnota stała się „Bożkiem naszego czasu”". Jak pisze:

Bożek wspólnoty umacnia swoją siłę przyciagania słabych tego świata - zrozumiały jako ideologia wykluczonych, rozczarowanych i oczekujących, jako ideologia proletariatu, ludzi zubożałych i czującej nadal kajdany młodzieży, usprawiedliwiony jako protest ludzi cierpiących z powodu wielkomiejskiego, zmechanizowanego i wykorzenionego życia. Pod jego hasłem powstały całe armie, a tysiące ludzi było gotowych na śmierć ${ }^{10}$.

Jak dalej, nieco ironicznie, zauważa Plessner:

Niejako dla zrównoważenia twardości i płytkości naszego życia idea ta [wspólnoty przyp. P.D.] zebrała w sobie wszystką słodycz aż do ckliwości, wszelką tkliwość do bezsilności, wszelką ustępliwość aż do braku godności. [...] Ogromne ochłodzenie ludzkich relacji przez maszynowe, handlowe, polityczne abstrakcje prowadzi do pojawienia się jego przeciwieństwa $\mathrm{w}$ ideale rozpalonej, żarzącej się we wszystkich swych członkach wspólnoty. Wyrachowaniu, brutalnemu robieniu interesów przeciwstawia się obraz szczęścia płynącego ze spontanicznego dawania siebie, pełnemu nieufności rozbiciu na opancerzone państwa - światowe przymierze narodów w celu ustanowienia wiecznego pokoju ${ }^{11}$.

Plessner wyprowadza stąd niezmiernie ważny dla naszych rozważań wniosek. Stwierdza mianowicie, że „Dlatego nie obowiązuje już prawo dystansu, osamotnienie utraciło swój czar" ${ }^{2}$.

Kongenialnie do Plessnera, na przechodzącą w „,ckliwość” „słodycz” wspólnoty zwraca uwagę także Zygmunt Bauman, powiadając: „«Wspólnota» brzmi dobrze: cokolwiek ono znaczy, dobrze jest «mieć wspólnotę», «być we wspólnocie». [...] Towarzystwo czy społeczeństwo bywają złe; ale nie wspólnota. Czujemy, że wspólnota zawsze jest czymś dobrym"13.

Nieżyjący już, niestety, (zmarł w roku 2001) Anthony Storr, angielski psychiatra i pisarz, wielokrotnie na kartach swojej znakomitej książki z roku 1988 pod tytułem Samotność: powrót do Jaźni ${ }^{14}$, w Polsce dopiero co wydanej, wska-

\footnotetext{
${ }^{9}$ H. Plessner, Granice wspólnoty. Krytyka radykalizmu społecznego, dz. cyt., s. 27.

${ }^{10}$ Tamże, s. 28.

${ }^{11}$ Tamże, s. 27.

12 Tamże.

${ }^{13}$ Z. Bauman, Wspólnota. W poszukiwaniu bezpieczeństwa w niepewnym świecie, dz. cyt., s. 5.

${ }^{14}$ Por. A. Storr, Samotność: powrót do jaźni, tłum. J. Prokopiuk i P.J. Sieradzan, Warszawa
} 2010. 
zuje, że w powszechnej świadomości ludzi zadomowiło się wcale nowe - dodam od siebie - przekonanie, którego najznakomitszym wyrazicielem na polu bliskiej profesji Storra psychoanalizy jest John Bowlby, czyniący to w trzytomowej rozprawie Attachement and Loss (Więź i strata), zgodnie z którym ,,[... zasadniczą potrzebą ludzi - od niemowlęctwa poczynając - jest wchodzenie w relacje $\mathrm{z}$ innymi. Relacje te są źródłem wsparcia i satysfakcji, a uniwersalna potrzeba „więzi" wykracza daleko poza potrzebę spełnienia seksualnego"15.

Temat wspólnoty i wspólnotowości, mimo swojej eksponowanej pozycji, ten tak - jak zauważa Storr:

Typowy dla dzisiejszych czasów nacisk na intymne relacje międzyludzkie, które uważane są za probierz zdrowia i szczęścia, to zjawisko stosunkowo nowe. Wcześniejsze pokolenia nie przywiązywały do tej kwestii tak dużej wagi, wierząc zapewne, że codzienna rutyna, zwykłe zadania, powinny dać nam wszystko, czego nam potrzeba. Być może ludzie byli tak zajęci zdobywaniem środków na życie i walką o przetrwanie, iż nie starczało im czasu, by poświęcać się subtelnościom i niuansom kontaktów z innymi ${ }^{16}$.

Według Ernesta Gellnera, na którego autorytet powołuje się Storr,

[...] nasze zainteresowanie i zatroskanie sferą stosunków międzyludzkich zastapiło niegdysiejsze niepokoje związane z nieprzewidywalnością i niebezpieczeństwami świata natury. [...] W dzisiejszych zamożnych społeczeństwach - jak twierdzi Gellner - większość z nas nie musi obawiać się chorób, nędzy, głodu i kataklizmów. Wcześniejsze pokolenia nawet o tym nie marzyły ${ }^{17}$.

Analogicznie rzecz się przedstawia w nauce. Beata Sierocka, na przykład, przypomina, że „Filozofia, a wraz z nią humanistyka i nauki społeczne potrzebowały zadziwiająco dużo czasu, by w swe struktury kategorialne włączyć pojęcie wspólnoty"18.

Można dodać od siebie, że w tym zakresie obydwa fenomeny, samotności i wspólnotowości, podzieliły ten sam los. Jeśli zgodzić się z Sierocką,

Po epokę klasyki niemieckiej (przede wszystkim po system Heglowski) nie było w zasadzie żadnych projektów, w których udałoby się chociażby antycypować problematykę wspólnotowości. Nie mówiąc już o możliwości oszacowania jej znaczenia - zarówno w wymiarze teoretycznym, jak i praktycznym. Jeszcze więcej czasu potrzebowali filozofowie na skonceptualizowanie sfery językowych procesów komu-

\footnotetext{
${ }^{15}$ Cyt. za: tamże, s. 27. Por. J. Bowlby, Attachement and Loss, vol. 1: Attachement, New York 1969, 1982.

${ }^{16}$ A. Storr, Samotność: powrót do jaźni, dz. cyt., s. 17.

17 Tamże.

${ }^{18}$ B. Sierocka, Stowo wstępne, w: Wspólnota komunikacyjna w teorii i praktyce, red. taż, dz. cyt., s. 5.
} 
nikacyjnych, a zwłaszcza na dostrzeżenie, że to na jej właśnie obszarze konstytuuje się specyfika ludzkiego bytu i ludzkiej wiedzy ${ }^{19}$.

To zafiksowanie na wspólnocie, jeśli wolno się tak wyrazić, bywa przez wielu autorów poczytywane za niebezpieczne. Plessner mówi wprost: „W świadomej rezygnacji z prawa do dystansu między ludźmi w ideale wspólnotowego rozpłynięcia się w poszerzającej się sieci organicznych więzi zagrożony zostaje człowiek"”20.

\section{VITA MIXTA: KONSONANS SAMOTNOŚCI I WSPÓLNOTOWOŚCI}

Charakterystyczna od zarania dla filozofii człowieka, filozofii społecznej czy filozofii politycznej tendencja do antagonizowania ze sobą ujęć samotności ze wspólnotowością okazała się jałowa, nieadekwatna, a nierzadko szkodliwa. W czasach najnowszych odżywa quattrocentowa idea vita mixta, która godząc się z antagonizmem samotności i wspólnotowości, równocześnie wskazuje, że istnieją one na zasadzie coincidentia oppositorum. Zasadnicze przesłanie pracy Plessnera, sygnalizowane zresztą samym jej tytułem, sugerującym konieczność przyjęcia istnienia i respektowania „granic wspólnoty”, streszcza się w nader wymownej obserwacji: „Nie chodzi o odrzucenie prawa wspólnoty życia, jej szlachetności i jej piękna. Chodzi o odrzucenie jej uznania za jedynie godną człowieka formę współistnienia; nie chodzi o odrzucenie communio, lecz odrzucenie communio jako jedynej zasady, odrzucenie komunizmu jako sposobu życia, odrzucenie radykalizmu wspólnoty"21.

Plessnerowi, tyle że na terenie psychoanalizy, wtóruje wspominany Anthony Storr. On także myślą przewodnią swojej rozprawy czyni uwagę, że na fenomeny samotności i wspólnotowości należy spojrzeć jako na komplementarne, mimo iż przeciwstawne sobie, nie zaś - jak to dotychczas funkcjonowało - jako na alternatywne opcje ${ }^{22}$. Tego rodzaju posunięcie ma, w przekonaniu Storra, zrehabilitować i dowartościować samotność jako miejsce twórczego i osobowościowego, pogłębionego rozwoju jednostki, a może także nawet jako ważną i użyteczną metodę procesu psychoterapeutycznego. Jak stwierdza on:

Miłość i przyjaźń są oczywiście istotną częścią wszystkiego tego, co nadaje życiu sens. Nie są jednak jedynymi źródłami szczęścia. [...] Wiele zwyczajnych zainteresowań i większość prawdziwie nowatorskich dążeń twórczych trwa i rozwija się bez udziału relacji interpersonalnych. Wydaje mi się, że to, co dzieje się z człowiekiem,

\footnotetext{
${ }^{19}$ Tamże.

${ }^{20}$ H. Plessner, Granice wspólnoty. Krytyka radykalizmu społecznego, dz. cyt., s. 27.

${ }^{21}$ Tamże, s. 45.

${ }^{22}$ A. Storr, Samotność: powrót do jaźni, dz. cyt., s. 13.
} 
gdy przebywa on sam ze sobą, nie jest wcale mniej ważne niż to, jak układają się jego stosunki z innymi²3.

I wreszcie, nieomal wypowiadając credo tezy o dialektycznym napięciu między samotnością a wspólnotowością, Storr konkluduje: „Naszym życiem kierują dwa sprzeczne dążenia - dążenie do posiadania towarzystwa, do miłości i wszystkiego innego, co zbliża nas do ludzi, i dążenie do niezależności, odrębności i autonomii" ${ }^{24}$.

\section{VITA PARADOXA: NIETOWARZYSKA TOWARZYSKOŚĆ}

Uwaga Storra eksplikuje, w istocie, doniosłą treść towarzyszącej filozofii samotności od samych jej początków, aczkolwiek przez wiele stuleci nierozwijanej, idei, która, w sławetnym sformułowaniu Kanta, stwierdza „nietowarzyską towarzyskość ludzi" [die ungesellige Geselligkeit der Menschen] ${ }^{25}$. W idei tej wyraża się, w sposób najokazalszy, naturalnie dialektyczne sprzężenie, jakie zachodzi między fenomenami samotności i wspólnotowości, tu określonymi jako „nietowarzyskość” i „towarzyskość”. W Metafizycznych podstawach nauki o cnocie królewiecki filozof, precyzując swój koncept, lakonicznie stwierdza, że „Człowiek jest istotą przeznaczoną do życia społecznego (chociaż zarazem mimo to nietowarzyską) [...]”26. Włodzimierz Galewicz tę - jak ją nazywa - „paradoksalną właściwość ludzi” ${ }^{27}$ objaśnia - za Kantem - okolicznością, w której „pociąg do tego, aby nawiązywać stosunki społeczne”28, równoważony jest „oporem, który grozi ich zerwaniem"29. Autor Metafizyki moralności ilustruje to napięcie przykładem powodującej ludźmi silnej, ,potrzeby zwi erzania się innym (nawet bez żadnego dalszego celu)" ${ }^{\prime 30}$ zderzonej ze strachem, ,jaki inni mogliby uczynić z tych wyjawionych im myśli’"31. Ów strach ma charakter ograniczający i prewencyjny. Jest on na tyle przemożny, że każe nam „u k ryw ać znaczną część swoich sądów (zwłaszcza o innych ludziach)”32. Jak pisze Kant:

${ }^{23}$ Tamże, s. 14.

${ }^{24}$ Tamże.

${ }^{25}$ I. Kant, Idea powszechnej historii w aspekcie kosmopolitycznym, tłum. M. Żelazny, w: tenże, Rozprawy z filozofii historii, przekład zbiorowy, Kęty 2005, s. 34. Por. Aspołeczna towarzyskość. Uwagi do pewnego pojęcia Kanta, thum. Z. Krasnodębski, w: H. Plessner, Pytanie o conditio humana. Wybór pism, wybrał, oprac. i wstępem opatrzył Z. Krasnodębski, tłum. M. Łukasiewicz, Z. Krasnodębski, A. Załuska, Warszawa 1988, s. 286-298.

${ }^{26}$ I. Kant, Metafizyczne podstawy nauki o cnocie, thum. W. Galewicz, Kęty 2005, § 47, s. 151.

${ }^{27}$ Zob. tamże, § 47, s. 151, przyp. 360.

${ }^{28}$ Tamże.

${ }^{29}$ Tamże

${ }^{30}$ Tamże, s. 152.

${ }^{31}$ Tamże.

${ }^{32}$ Tamże. 
[Człowiek - uzup. P.D.] Chętnie by z kimś porozmawiał o tym, co sądzi o osobach, z którymi obcuje, o rządzie, o religii itd., ale nie może tego ryzykować: w części dlatego, że ten drugi, który ostrożnie zachowuje swój sąd dla siebie, mógłby użyć jego zwierzeń ze szkodą dla niego, w czesści zaś dlatego, że gdy chodzi o wyjawianie własnych błędów, drugi mógłby zachować swoje w tajemnicy, tak iż on sam straciłby jego szacunek, gdyby zupełnie szczerze przed nim się odsłonił33.

Ten jakże czytelny, choć jednostkowy i prozaiczny, przykład występowania „nietowarzyskiej towarzyskości” pozwala uchwycić jeden z ważnych aspektów dialektyki samotności i wspólnotowości, a w szerszym planie dialektycznego charakteru ludzkiej egzystencji. Jest nim, mianowicie, ontologicznie nośne sprzężenie zwrotne zachodzące między pragnieniem otwartości (bycia otwartym wobec innych) a koniecznością częściowego lub całkowitego zamykania się przed innymi. Z drugiej strony casus ,nietowarzyskiej towarzyskości” obrazuje doniosłą etycznie koincydencję szczerości w postępowaniu i odnoszeniu się do innych, która jednak - o paradoksie, z uwagi na nich właśnie, a tylko pośrednio ze względu na siebie - domaga się stosowania rozlicznych hamulców i kamuflaży, gdy tymczasem chciałoby się z nich zrezygnować zupełnie lub co najmniej częściowo. Niejako przy okazji mamy tu do czynienia z ciekawym moralnym paradoksem - by posłużyć się określeniem Saula Smilansky'ego ${ }^{34}$. Jest to paradoks częściowej lub całkowitej nieprzystawalności naszych oczekiwań (roszczeń) moralnych wobec okoliczności, z którymi przychodzi nam się konfrontować. Z jednej strony bowiem gotowiśmy okazywać innym szczerość, z drugiej strony jednak - obawiając się (niestety nierzadko w sposób wysoce uzasadniony) nieszczerości, jaką ci mogliby wobec nas uzewnętrznić - powściągamy samych siebie przed porywem szczerości, wbrew sobie - lecz dla własnego pożytku - stając się jawnym lub skrytym obłudnikiem. Na ogół jednak nasze działanie zaprawione jest mieszaniną ich obydwu - to jest wspólnototwórczej szczerości i skazującego na taką lub inną samotność, chroniącego przed negatywnymi jej konsekwencjami wycofania w milczenie, pozorowanie, kłamliwość czy przewrotność. Przystajemy na to - jak to odnotowuje, na przykład, Leszek Kołakowski ${ }^{35}$ - że w relacjach międzyludzkich, mimo dosyć powszechnej akceptacji dla wymogu prawdomówności, istnieje daleko idące przyzwolenie dla zachowań mniej lub bardziej z nim sprzecznych. Paradoksalności omawianej sytuacji dodaje fakt, że obustronne roszczenie szczerości zderza się ponadto ze wzajemnym podejrzewaniem się o nieszczerość. Działanie moralne często więc sprowadza się do poszukiwania znośnego dla stron balansu między wskazanymi postawami, jakkolwiek zdarzają się osoby, które nie honorują takich lub żadnych kompromisów moralnych, opo-

${ }^{33}$ Tamże.

${ }^{34}$ Zob. S. Smilansky, 10 moralnych paradoksów, tłum. W. Kostrzewski, Kraków 2009.

${ }^{35}$ Zob. L. Kołakowski, Mini wykłady o maxi sprawach, Seria pierwsza, O kłamstwie, Kraków 2005, s. 29-35. 
wiadając się za maksymalną szczerością bądź całkowitą fasadowością w relacjach $\mathrm{z}$ innymi. W kontekście przewodniego zagadnienia artykułu warto zauważyć prostą, acz znamienną zależność, zachodzącą między samotnością i wspólnotowością z jednej strony a szczerością i pozoranctwem z drugiej. Szczerość bowiem (co najmniej na poziomie intencji) sprzyja budowaniu wspólnoty poprzez pozyskiwanie jednego z najistotniejszych jej budulców, mianowicie zaufania; zarazem jednak (na poziomie faktycznych interakcji społecznych) jej nadmiar postrzega się jako szkodliwy dla trwałości tej wspólnoty. Wówczas szczerość, ustępując miejsca nieszczerości, staje się przyczyną samotności (poczucia odosobnienia, wyobcowania lub osamotnienia), gdy z kolei nieszczerość zyskuje jako budulec wspólnoty. W rezultacie, jak o tym świadczą także już pierwsze starożytne teksty filozofów, zainteresowanych problemem samotności, to samotność zyskuje jako sojuszniczka i enklawa szczerości, podczas gdy życie społeczne in genere daje więcej przyzwolenia i zachęty dla zachowań fasadowych, opartych na nieszczerości.

Uogólnienie tej obserwacji łączy się z trzecim aspektem „nietowarzyskiej towarzyskości”, mającym antropologiczną rangę, którym jest przemaganie się z sobą autentyczności z nieautentycznością ludzkiego życia. To niezwykle frapujący i rozległy temat, zasługujący na osobne potraktowanie. Tu poprzestajemy jedynie na konstatacji jego ważności dla filozofii samotności, zaznaczając równocześnie, że na ogół - szczególnie w przypadku jej indywidualistycznej orientacji, skupiającej w sobie ontoegzystencjalną, kontemplatywną i libertalną wykładnię samotności - autentyczność kojarzy się w niej z samotnością, we wspólnotowości, dla odmiany, upatrując moralnie podejrzanej (respective dwuznacznej) tendencji, będącej wyrazem ludzkiej przeciętności, niedojrzałości, niesamodzielności, nieoryginalności (wtórności), szablonowości, bezkrytycznego naśladownictwa, konformistycznej służalczości, asekuranctwa, gry pozorów, a w końcu prymitywnie pojętej towarzyskości, motywowanej nieumiejętnością sprostania wyzwaniu, jakim jest samotność i związane z nią odosobnienie, milczenie i głęboko penetrująca naszą samoświadomość oraz „dobre” (choć na ogół zafałszowane) samopoczucie, autorefleksja.

Z dialektyką samotności i wspólnotowości w przestrzeni odniesień moralnych znacząco współbrzmi Kantowska dialektyka miłości i szacunku, dla których filozof ten poszukuje - jak sam rzecz określa - „harmonijnej proporcji równowagi" ${ }^{36}$. Tłumaczy ją możliwością traktowania miłości jako „przyciagania”, szacunku zaś jako „odpychania” między wchodzącymi w relację stronami, „, podczas gdy zasada miłości każe [przyjaciołom] zbliżać się do siebie, zasada szacunku każe im zachowywać wobec siebie należyty dystans"37, a wszystko po

\footnotetext{
${ }^{36}$ I. Kant, Metafizyczne podstawy nauki o cnocie, dz. cyt., § 46, s. 149.

${ }^{37}$ Tamże, s. 150.
} 
to, by uniknąć, nawet w największej przyjaźni, takiego stopnia spoufalenia ze sobą, które nadweręża zasadę szacunku lub jej uchybia, czyniąc całą tę relację w najlepszym razie - raptem „towarzyską formą,"38. Wynika więc z tego, że wspólnototwórcza zasada miłości - wbrew potocznym, zestereotypizowanym mniemaniom - wymaga zrównoważenia jej przez proporcjonalne - gwoli osiagnięcia między nimi pożądanej harmonii - stosowanie także zasady szacunku, korelującego z samotnością - nie w tym jednak sensie, iżby chodziło o szacunek okazywany wyłącznie samemu sobie w separacji od innych i pogardzie dla nich, lecz w tym, że dopiero samotność - ot, choćby tak prozaiczna, jak zwykłe, tymczasowe odosobnienie (powstałe, na przykład, w wyniku rozłąki) - stwarza warunki sprzyjające nabraniu odpowiedniego dystansu do osoby lub osób, którym winniśmy, prócz miłości, okazywać szacunek.

\section{DWUMIAN LECZNICZY SENEKI FILOZOFA}

Tym, który jako pierwszy wyeksponował dialektyczną biegunowość ludzkiej egzystencji, był Seneka Filozof. W dialogu O pokoju ducha poczynił on zalecenie, które - na wzór znanego Epikurowskiego czwórmianu - nazywam dwumianem leczniczym Seneki. Głosi on, że „Musimy jednak mieszać i wzajemnie przeplatać dwie rzeczy: samotność i obcowanie z ludźmi. Samotność będzie w nas budzić tęsknotę za ludźmi, ludzie - za nami. I w ten sposób jedno stanie się dla drugiego lekarstwem - niechęć do ludzi uleczy samotność, niechęć do samotności - przebywanie pomiędzy ludźmi”"39.

Wypowiedź Seneki ma charakter i przeznaczenie wyraźnie praktyczne. Nie sięga ona jeszcze ontologicznej warstwy humanum, lecz zatrzymuje się na prakseologicznej powierzchni bytu. Rozpoznając mechanizmy funkcjonowania jednostki w społeczeństwie oraz konsekwencje ich wzajemnego oddziaływania na siebie, neostoik rzymski zmierza do ich zharmonizowania i usprawnienia ich współdziałania poprzez eliminację zagrożeń, jakie wynikają z uprzywilejowania bądź wybijającej się na niepodległość respective odcinającej się od społeczeństwa jednostki, bądź dążącego do hegemonii respective podporządkowującego sobie jednostki społeczeństwa.

Ważnym - a kto wie, czy nie najważniejszym - punktem filozoficznego panaceum Seneki na egzystencjalne bolączki człowieka jest czas. $Z$ niestrudzonym uporem, ilekroć dyskutuje problem samotności - podobnie zresztą, jak to czyni i w innych przypadkach - odwołuje się do kryterium temporalnego, na co wskazuje chociażby nagminne posługiwanie się przez niego to przysłówkami frekwen-

\footnotetext{
${ }^{38}$ Tamże.

${ }^{39}$ L.A. Seneka, O pokoju ducha, dz. cyt., XVII 3, s. 661-662 (wyd. z 1963, s. 541).
} 
tatywnymi (często, rzadko, z rzadka), to przysłówkami duratywnymi (stale, ciągle, wciąż, zawsze, nigdy, zwykle, zazwyczaj, nadal, na ogół, przeważnie). Demonstrowane przez Senekę lecznicze właściwości samotności z jednej strony i obcowania $\mathrm{z}$ ludźmi z drugiej wyraźnie wiążą się z temporalnym ich określeniem, a ściślej z periodycznością oraz cykliczną powtarzalnością każdego z nich. Senekowska dialektyka samotności i wspólnotowości operuje więc na jednostkach czasu - i to rozwiązanie wydaje się co najmniej optymalne, jeśli nie najwłaściwsze. Zbyt długa samotność to - by posłużyć się jakże adekwatnie brzmiącym, w tym kontekście, sformułowaniem Bohumila Hrabala - „zbyt głośna samotność" ${ }^{40}$. Analogicznie do tego, nazbyt przeciagłe otaczanie się ludźmi i przebywanie wśród nich i z nimi skutkuje trudnym do opanowania zamętem i rozstrojeniem. Stają się one z czasem tak intensywne i rozległe, że właściwie należałoby powiedzieć, iż to one przejmują zwierzchność nad tymi, którzy im ulegają.

Tę głęboką, filozoficzną intuicję autora słynnych Dialogów potwierdzają i rozwijają - choć nie miejsce na to, by je tu wszystkie uwypuklać i detalicznie omawiać ${ }^{41}$ - prowadzone już od końca lat pięćdziesiątych ubiegłego wieku badania przedstawicieli takich dyscyplin, jak psychiatria, psychologia, psychoanaliza, a także filozoficzna psychologia, ukierunkowanych na naukową eksplorację, diagnostykę i terapię samotności. Naukowym standardem jest dziś twierdzenie, że samotność, jej charakter, natężenie, przebieg i konsekwencje, do jakich prowadzi, są funkcją oddziaływania czynnika temporalnego i różnicują się w zależności od długości jej trwania. Oznacza to, że czas nie tylko nie pozostaje bez związ$\mathrm{ku} \mathrm{z}$ samotnością, lecz że stanowi on jeden $\mathrm{z}$ najbardziej podstawowych i ważnych jej stymulatorów. Pisze o tym, na przykład, światowej klasy znawca problematyki, dziś już emerytowany profesor filozofii i filozoficznej psychologii w montrealskim Concordia University, John G. McGraw ${ }^{42}$, w książce Samotność: studium psychologiczne i filozoficzne, gdzie czytamy:

[...] samotność może zmieniać się w swojej intensywności przeżywania od łagodnie drażniącej do dotkliwie wyniszczającej. W kategoriach ilościowych samotność może wahać się od pojedynczego, przelotnego incydentu do często występujących, przedłużających się okresów. Samotność, która trwa dłużej niż dwa lub więcej następujących po sobie lat może być określona jako chroniczna. [...] Samotność, która trwa krótko

${ }^{40}$ B. Hrabal, Zbyt głośna samotność, tłum. P. Godlewski, Izabelin 2003, s. 53, 65-66.

${ }^{41}$ Częściowo czynię to w osobnym artykule, do którego lektury niniejszym zachęcam i odsyłam. Por. P. Domeracki, Cierpienie w samotności - samotność w cierpieniu, w: Doświadczanie choroby w perspektywie badań interdyscyplinarnych, red. B. Płonka-Syroka i M. Skrzypek, Wrocław 2010, s. 199-208.

${ }^{42}$ Zob. szczeg. ostatnie prace tego autora: J.G. McGraw, Intimacy and Aloneness. A Multivolume Study in Philosophical Psychology, v. 1: Intimacy and Isolation, Value Inquiry Book Series, v. 221, Amsterdam 2010; tenże, Intimacy and Aloneness. A Multi-Volume Study in Philosophical Psychology, vol. 2: Personality Disorders and States of Aloneness, Amsterdam-New York 2012. 
i ma charakter incydentalny może zostać określona mianem przejściowej. [...] Innymi słowy, im dłużej trwa samotność, tym bardziej jest ona dotkliwa i niszcząca ${ }^{43}$.

Podobnymi kategoriami, na gruncie psychologii, operują Zofia Dołęga, posługująca się określeniami „samotność krótkotrwała” i „długotrwała”"44, oraz Carolyn Cutrona, która od strony temporalnej charakteryzuje samotność jako „epizodyczną" lub „chroniczną"45.

Z Senekowskiego dictum wyłania się zatem niebanalna zachęta, by periody wspólnotowości mieszać i przeplatać periodami samotności i na odwrót. Przedłużanie się w czasie któregokolwiek z nich grozi niechybnie katastrofalną w skutkach chronicznością. Dotyczy to, jak z tego wynika, nie tylko samotności, lecz także jej przeciwieństwa. Na ogół zwraca się uwagę wyłącznie na negatywne aspekty jedynie samotności. Tymczasem Seneka, podobnie jak wielu późniejszych filozofów (choć każdy z nich czynił to w różnych odsłonach i proporcjach, a przy tym każdy na swój własny sposób i rachunek) - z wyjątkiem poprzedzającego go w tym poglądzie Epikura - takich chociażby jak: Franciszek Petrarka, Michel de Montaigne (inspirujący się zresztą, w tym względzie, stanowiskami zajmowanymi przez Epikura i Senekę $e^{46}$ ), Pierre Charron (przyjaźniący się de facto $\mathrm{z}$ Montaigne'em i wzorujący, w znacznej mierze, na nim $^{47}$ ), Thomas Hobbes, Blaise Pascal, Bernard Mandeville, Jan Jakub Rousseau, Arthur Schopenhauer, Søren Kierkegaard, Friedrich Nietzsche czy Jean-Paul Sartre - uczula także na negatywne aspekty życia społecznego i takiż jego wpływ na poszczególnych jego uczestników, gdy całkowicie ich ono pochłonie, biorąc nad nimi górę, co zachodzi z reguły wówczas, gdy pokładają w nim przesadną nadzieję, upatrując dla siebie samej tylko szczęśliwości. W dialogu $O$ gniewie Seneka wyznaje ku przestrodze:

O wszystkim winieneś myśleć, wszystkiego masz się spodziewać. Wszak nawet w dobrych charakterach znajdzie się coś przykrego. Rodzi natura ludzka usposobienia podstępne, rodzi niewdzięczne, rodzi chciwe, rodzi bezbożne. [...] Z czego się najbardziej radujesz, tego musisz się najbardziej obawiać. Gdzie wszystko wydaje ci

${ }^{43}$ J.G. McGraw, Samotność. Studium psychologiczne i filozoficzne, tłum. A. Hankała, Warszawa 2000, s. 16. Zob. też: J.E. Young, Loneliness: Depression and Cognitive Therapy. Theory and Application, in: Loneliness. A Sourcebook of Current Theory, Research and Therapy, eds. L.A. Peplau, D. Perlman, New York 1982, s. 379-405; szczeg. s. 382.

${ }^{44}$ Z. Dołęga, Samotność młodzieży, dz. cyt., s. 18.

${ }^{45}$ C. Cutrona, Transition to College. Loneliness and the Process of Social Adjustment, in: Loneliness. A Sourcebook of Current Theory, Research and Therapy, s. 291-309.

${ }^{46}$ Por. M. de Montaigne, Próby, ks. 2, tłum. T. Żeleński (Boy); oprac., wstępem i koment. opatrzył Z. Gierczyński; [cytaty łac. i grec. tłum. T. Sinko i E. Cięglewicz], Warszawa 1985, s. 344-345 .

${ }^{47}$ Zob. na ten temat: B. Suchodolski, Rozwój nowożytnej filozofii człowieka, Warszawa 1967, s. 280 . 
się bezpieczne, tam nie brak rzeczy, które ci szkodę wyrządzą, choć chwilowo znajdują się w stanie spoczynku. Pamiętaj, że zawsze coś przyjdzie, co w ciebie ugodzii ${ }^{48}$.

Samotność leczy więc niedostatki ustroju społecznego i społecznych praktyk, te $\mathrm{z}$ kolei stanowią antidotum na niedomogi samotności. Trzeba jednak pamiętać, że do jej powstania przyczyniają się nie tylko względy natury podmiotowej (a wśród nich w szczególności: temperament, osobowość, charakter, emocjonalność, wrażliwość, predyspozycje, inklinacje, światopogląd, przekonania, wierzenia, cele), ale też - i to w nie mniejszym zakresie i stopniu - czynniki pochodzenia społecznego. Toteż nie tylko introwertyk, z racji swojej przyrodzonej skłonności do zamykania się w sobie, więcej od innych narażony jest na samotność, ale też spodziewać się jej musi oporny na nią ekstrawertyk, któremu kontakty z innymi - co bywa trudne do uniknięcia, gdy do nich dochodzi - przyniosą już to rozczarowanie, już to: utrapienie, zawód, rozgoryczenie, obawę (niepewność, poczucie zagrożenia lub osaczenia), gniew, frustrację, dezorientację, kłamstwo, zdradę, oszustwo, nieufność, niesmak, odrazę, żal, smutek, znużenie, wypalenie, odrętwienie, marazm, strapienie, rozdrażnienie, zniechęcenie, rozstanie, tęsknotę, rozpacz, chłodne zdystansowanie, demoralizację, obmowę, posądzenia, niewdzięczność, zlekceważenie, obrazę, upokorzenie, pogardę, wrogość, nienawiść, wyszydzenie, marginalizację, napiętnowanie, dezaprobatę, odrzucenie, wykluczenie, przemoc i wiele innych, tym podobnych.

\section{ZACISZE ODOSOBNIENIA}

Senekowska pochwała samotności, definiowanej jako od os obnienie pojęte w kategoriach: oderwania ducha od rzeczy zewnętrznych ${ }^{49}$, zamknięcia się $\mathrm{w}$ zaciszu własnego domostwa ${ }^{50}$, ukrycia domowego ${ }^{51}$, schronienia się $\mathrm{w}$ ustronie przed działalnością publiczną ${ }^{52}$, wejścia $\mathrm{w}$ siebie ${ }^{53}$ i przestawania $\mathrm{z}$ samym sobą (z własnym duchem) $)^{54}$, jest w gruncie rzeczy pochwałą wolności, mądrości i szlachetności. Te zaś możliwe są do osiagnięcia jedynie w wymiarze indywidualnym jako wolność, mądrość i szlachetność konkretnych jednostek. Triumwirat tych cnót symbolizuje zespolenie trzech domen: obywatelskiej (wolność), intelektualnej (mądrość) i moralnej (szlachetność). Społeczeństwo, jako organizm

${ }^{48}$ L.A. Seneka, O gniewie, w: tenże, Dialogi, tłum. L. Joachimowicz, Warszawa 1963, XXXI 5, s. 233.

${ }^{49}$ Tenże, O pokoju ducha, dz. cyt., XIV 2, wyd. z 1963, s. 534.

${ }^{50}$ Tamże, I 11, wyd. z 1989, s. 616 (wyd. z 1963, s. 500).

${ }^{51}$ Tamże, III 2, s. 625-626 (wyd. z 1963, s. 509).

${ }^{52}$ Tamże, III 3, s. 626 (wyd. z 1963, s. 509).

53 Tamże, XIV 2, wyd. z 1963, s. 534.

${ }^{54}$ Tamże, I 11, wyd. z 1989, s. 616 (wyd. z 1963, s. 500). 
tworzony przez jednostki, może się rozwinąć w kierunku tych wartości, wyłącznie jeśli powściągnie anihilującą wszelkie przejawy indywidualności skłonność do totalizacji. Autorowi Listów moralnych do Lucyliusza idzie zatem o zachowanie właściwych proporcji między tym, co indywidualne, a tym, co zbiorowe. Owszem, zbiorowość może skutecznie tłumić inicjatywę jednostek, czyni to jednak z pozycji siły, lecz nie jest to siła ducha. Ta bowiem należy do samych jednostek. Dopiero silne - w znaczeniu wielkie duchem - jednostki gwarantują ład prawdziwie silnego społeczeństwa.

Nacisk, jaki Seneka kładzie na jednostkowość, należy tłumaczyć wpływem wywodzącej się od Sokratesa tradycji psychoantropologicznej. Stwierdza się w niej tożsamość człowieka i jego duszy ${ }^{55}$, upatrując w niej jego istotowy wyróżnik. Skoro tak, to naczelnym imperatywem etyki, a zarazem moralna powinnością każdego człowieka staje się troska o własny rozwój duchowy. Wymaga ona, jako warunku dla dokonywania się tego rozwoju, samotności wyrażającej się w odosobnieniu, nie zaś społecznej wrzawy, krzątaniny i systemu zależności, w których upodobanie znajdują szczególnie pospolite umysły ${ }^{56}$. Nie chodzi tu jednak o realizację Epikurowskiego ekstremum apatrydyczności. Życie w ukryciu, ,wycofanie się z życia publicznego" do domowego zacisza ${ }^{57}$, nie oznacza mizantropijnej ucieczki przed ludźmi i tworzonymi przez nich instytucjami w daremną bezczynność i gnuśność. Jego sens wyraża się w woli służenia „zdolnościami umysłu, słowem, radą” poszczególnym ludziom i w ogóle wszyst$\mathrm{kim}^{58}$. Seneka był niezbicie przekonany, że bycie pożytecznym dla państwa nie sprowadza się wyłącznie do wystawionego na widok publiczny zaangażowania w politykę, administrację, sądownictwo czy militaria, lecz obejmuje ono także jeśli nie przede wszystkim - dbałość o moralną formację członków społeczeństwa, w tym zaś szczególnie młodzieży ${ }^{59}$. Unikanie działalności publicznej nie jest więc uchylaniem się od odpowiedzialności za dobro wspólne, lecz stanowi alternatywną formę jego budowania i pomnażania. Jedynie bowiem w odosobnieniu, jak twierdzi Seneka, kształtuje się prawdziwa mądrość, hart ducha i cnota. Ten zaś, kto je posiądzie, zdobywa autorytet „dobrego nauczyciela obyczajności”" ${ }^{60}$, który daje mu tytuł do zaszczepiania cnoty w duszach i powstrzymywania ,tych, którzy na oślep gonią za pieniędzmi i użyciem zmysłowym"61. Nauczyciel moralno-

\footnotetext{
${ }^{55}$ Por. Platon, Alkibiades I i inne dialogi oraz definicje, thum. L. Regner, Warszawa 1973, 128 d - 130 e. Zob. też: G. Reale, Historia filozofii starożytnej, t. 1, tłum. E.I. Zieliński, Lublin 1999, s. 316.

${ }^{56}$ L.A. Seneka, O pokoju ducha, dz. cyt., II 11, wyd. z 1963, s. 506, XII wyd. z 1963, s. 531-532 .

${ }^{57}$ Tamże, II 9, wyd. z 1963, s. 505.

${ }^{58}$ Tamże, III 3, wyd. z 1963, s. 509.

${ }^{59}$ Tamże, III 3-5, wyd. z 1963, s. 509-510.

${ }^{60}$ Tamże, III 3, wyd. z 1963, s. 510.

${ }^{61}$ Tamże.
} 
ści, pomimo lub raczej właśnie dlatego, że zewnętrznie wycofany z wartkiego nurtu życia społecznego, „we własnym domu sprawuje urząd publiczny”62, tworząc od wewnątrz jego duchowe zręby.

\section{KRYJÓWKA WYOBCOWANIA}

Myliłby się jednak ten, kto by sądził, że doskonalenie moralne wymaga posuniętego do skrajności radykalizmu, jak to sobie wielu fanatycznie wyobraża. Jakkolwiek samotność w formie odosobnienia stanowi konieczny warunek możliwości i naturalne środowisko kształtowania się i wzrostu świadomości moralnej, to jednak nie stanowi ona celu i wartości samej w sobie. Warto pamiętać, że nie tylko w opinii Seneki, ale w ogóle każdego filozofa antyku grecko-rzymskiego, sławiącego przymioty samotności, uchodzi ona, przy całej swojej krasie, li tylko za narzędzie, służące nobliwszym od niej, ponadpartykularnym celom. Mechanizm działania moralnego funkcjonuje prawidłowo jedynie w sprzężeniu zwrotnym, zachodzącym między sferą prywatną a domeną publiczną. Eksterioryzacja, hegemonizacja i kolonizacja jednej przez drugą uruchamia łańcuch reakcji (zachodzących czasem procesualnie, czasem gwałtownie, czasem skokowo), przebiegający od postępującej patologizacji, przez obstrukcję i następująca po niej degenerację, na ostatecznej destrukcji dziedziny moralnej kończąc. Mając to na uwadze, kierowany szlachetnym zmysłem adekwatnie proporcjonalnego ważenia racji, Seneka przestrzega przed e k s tre m i $\mathrm{zacj}$ a $\mathrm{samotności,} \mathrm{która} \mathrm{nieuchronnie} \mathrm{prowadzi} \mathrm{do} \mathrm{uwikłania} \mathrm{się} \mathrm{w} \mathrm{per-}$ spektywę wakuumologiczną ${ }^{63}$. To zaś staje się możliwe, gdy, miast zadowolić się heterotelicznie zorientowanym odosobnieniem, czyni się zeń wartość samą w sobie. To, z kolei, wymaga przeskalowania perspektywy i uruchomienia działań monowektorowych, nastawionych na intensyfikację i radykalizację samotności, w wyniku których dochodzi do jej wynaturzenia. W ten sposób powstaje diametralnie różny od odosobnienia rodzaj samotności, który można określić mianem w y bc ow ania. Charakteryzuje się ono niepohamowanym, sukcesywnym przesuwaniem jej granic na skraj introwersji, apatrycji ${ }^{64}$ i egotyczności.

${ }^{62}$ Tamże.

${ }^{63}$ Terminem tym, mającym oznaczać naukę o pustce (z łac. 'vacuum' - 'próżnia', 'pustka' i gr. 'logos' - 'nauka'), posłużyli się redaktorzy naukowi monografii Człowiek i pustka, Zbigniew Hull i Witold Tulibacki, od których go zapożyczam. Zob. Człowiek i pustka. Problemy wakuumologii, red. Z. Hull i W. Tulibacki, Olsztyn 2000. Łaciński źródłosłów pierwszego członu terminu 'wakuumologia' - 'vacuum' pochodzi od przymiotnika 'vacuus', który ma szereg interesujących konotacji, w tym z samotnością. 'Vacuus' bowiem to taki, który jest 'opuszczony przez ludzi', zatem 'pusty', 'samotny', ale też 'wolny' w sensie 'nieżonaty', 'niezamężna', a do tego 'bezbronny', 'bez opieki', 'cichy', 'spokojny', wreszcie 'czczy', 'próżny', 'bez znaczenia'.

${ }^{64}$ „A p a t r y c j a” jest to cecha apatrydy lub/i węzłowy element apatrydyzmu, który polega na 
W rzeczywistości intelektualnie płodne i moralnie ożywcze u krycie odos obnienia zamienione zostaje na podszyty frustracją i lękiem, napędzany „struktura przeciwieństwa” ${ }^{65}$, każącą wszędzie z góry wietrzyć wroga, odruch ucieczki do Tischnerowskiej „kryjówki”" ${ }^{66}$. Kto decyduje się na taką samotność, ten winien zrazu uzmysłowić sobie, że mocą tej decyzji nie tylko konserwuje swoje „kryjówkowe” status quo, lecz, rejterując z życia publicznego, bierze na siebie trudny do wyobrażenia (a jeszcze trudniejszy do podźwignięcia) ciężar społecznej anihilacji. Tym dobitniej Seneka ostrzega, że „[...] jeśli zerwiemy wszelkie stosunki ze światem, jeśli odgrodzimy się murem od społeczeństwa i będziemy żyć zamknięci we własnym wnętrzu, wtedy tego rodzaju samotność, pozbawiona szlachetnych dążeń, wytworzy tylko wokół nas próżnię" ${ }^{97}$.

Kiedy odosobnienie pozostaje (zachowuje i potwierdza naturalną tendencję człowieka nazywaną) u s p ołe c znienie m, tedy wyobcowanie staje się jego antypodyczną odwrotnością, którą najtrafniej i najzwięźlej można określić jako ods p oł e c z n i en i e. Zasadniczo przejawia się ono w symptomatycznej postaci dojmującego poczucia obcości szeroko pojętego świata, w tym szczególnie Lebensweltu (świata życia codziennego), skorelowanego z poczuciem własnej obcości w stosunku do tak percypowanego (wyobrażonego) świata. To ostatnie zasadza się na nieodpartym przekonaniu o nieprzystawaniu do rzeczywistości, na której trwanie - w związku z generowanym przez nią poczuciem samowyobcowania - nie ma zgody. Osoba, która zaznaje wyobcowania, gotowa jest więc imać się działań tyleż gwałtownych, co rozpaczliwych, o ile w ogóle zdecyduje się wychylić ze swojej kryjówki. Tak oto wyobcowanie determinuje postawy i zachowania, które cechują się: brakiem dystansu do samego siebie; przekonaniem o nieposiadaniu deficytów społecznych i towarzyskich; programowym kontestowaniem zasad rządzących życiem społecznym; bezkrytycznym uznawaniem nienaruszalności i wyższości własnych racji; katapultowaniem się z zaangażowania społecznego innego niż obojętność, opór, bunt, negacja, odmowa czy protest; dysymilacją (wypieraniem, odrzucaniem, piętnowaniem) treści społecznie relewantnych; zacięciem reformatorskim; afektowanym moralizatorstwem; a ponadto wyraźnie odczuwalną rezerwą wobec innych, podatną na wyradzanie się w antagonizm, wrogość lub nienawiść.

Takie bywają efekty zatracania granic, zarówno w aspekcie dystansu, jak i zaangażowania. Dla prawidłowego - zrównoważonego funkcjonowania człowieka w społeczeństwie winno się te dwie perspektywy dialektycznie sprzęgać i równoważyć.

programowym unikaniu, celowej ucieczce od uczestnictwa w życiu publicznym i zaangażowania politycznego.

${ }^{65}$ Por. J. Tischner, Filozofia dramatu. Wprowadzenie, Paris 1990, s. 66.

${ }^{66}$ Tamże. Por. także: tenże, Wartości i myślenie, rozdz. 4: Ludzie z kryjówek, w: tenże, Myślenie wedtug wartości, Kraków 1993, s. 437-456.

${ }^{67}$ L.A. Seneka, O pokoju ducha, dz. cyt., III 7, wyd. z 1963, s. 511. 
Odosobnienie zatem tym zasadniczo różni się od wyobcowania, że stanowi pozytywny aspekt samotności; pozytywny w tym sensie, że w akcie odosobnienia - inaczej niż to zachodzi w wyobcowaniu - dokonuje się naraz afirmacja i konfirmacja uspołecznienia oraz wynikających zeń dążeń wspólnototwórczych. Odosobnienie pozwala postrzegać i traktować zarówno samego siebie, jak i otoczenie społeczne, w którym przebywamy, w sposób adekwatny, kierowany troską o konstruktywną zmianę, korektę, naprawę, udoskonalenie, usprawnienie, modernizację, wzrost i postęp. Odosobnienie pozwala także zrozumieć, że zabieganie o nie ma zwykle charakter procesualny, a nie natychmiastowy, gwałtowny, skokowy czy rewolucyjny. Osobę zdolną do trwania w odosobnieniu cechuje umiarkowany optymizm i wyważona samokrytyka, nakazująca wszelką projektowaną zmianę zaczynać zawsze od siebie.

Wyobcowanie, z kolei, należy postrzegać w kategoriach zniekształconej, zaburzonej i zderegulowanej optyki poznawczo-moralnej. Towarzyszą mu bowiem dekadencki nastrój, permanentne czarnowidztwo, wieczne rozczarowania, a ponadto przekonanie o własnej wyższości, przeświadczenie o przeznaczeniu do naprawczej misji świata, radykalizm przedsiębranych rozwiązań, gwałtowność działań, rewolucyjność, natychmiastowość oraz myślenie życzeniowe. Osobę wyobcowaną znamionuje wyolbrzymiony pesymizm, a także zupełny brak samokrytyki. W mniemaniu takiej osoby wszelką zakładaną zmianę zaczyna się zawsze od innych. To oni bowiem wymagają sanacji, polegającej na dostosowaniu parametrów ich postaw i zachowań do wyobrażonego wzorca.

\section{MONOLEKTYKA ${ }^{68}$ WSPÓLNOTOWOŚCI I SAMOTNOŚCI}

Samotność o wiele częściej, niż się na ogół sądzi, ma charakter egzogenny (jest pochodzenia społecznego) aniżeli endogenny (jest konsekwencją osobowościowo-charakterologicznych uwarunkowań danej jednostki). Stosunkowo mało jednak w literaturze przedmiotu - co się przekłada także na stan świadomości społecznej - zwraca się na to uwagę, uporczywie podkreślając nieomal zbawcze przymioty społeczeństwa, przy równoczesnym demonizowaniu samotności, co

\footnotetext{
${ }^{68}$ Terminem 'mo no le ktyka' posługuję się dla odróżnienia i charakterystyki ujęcia, podejścia, stanowiska czy koncepcji przeciwstawnych optyce dialektycznej i waloryzujących, zwracających uwagę czy podkreślających jedną tylko cechę, własność, funkcję, aspekt czy stronę badanego zjawiska lub problemu. Monolektyka wspólnotowości oznacza więc - tak w teorii, jak w praktyce (społecznej, moralnej, politycznej i kulturowej) - traktowanie wspólnotowości jako podstawowego, kluczowego i jedynego wymiaru, określającego ludzką egzystencję. Monolektyka samotności oznacza, z kolei, diametralnie przeciwstawne temu stanowisko, zgodnie z którym to samotność, a nie wspólnotowość, stanowi podstawowy, zasadniczy i wiodący aspekt ludzkiej egzystencji. Podejście d i a le k t y c z n e czyni jedno i drugie, wspólnotowość i samotność korelatami, dwiema stronami tej samej egzystencji.
} 
zresztą, ożywając własnym życiem, zaczyna funkcjonować na zasadzie samospełniającej się przepowiedni. Zaszczepianie i utrwalanie wśród ogółu jako jedynie uprawnionego - stąd, w istocie, bezdyskusyjnego, przekonania, że człowiek jest istotą społeczną oraz że jest nią do tego stopnia, iż umiejętność oraz chęć kooperowania z innymi determinuje wręcz jego wartość jako osoby, a także nadaje walor i sens jego życiu - niezależnie nawet od jego własnych predyspozycji, upodobań, zapatrywań i skłonności albo wbrew nim - z konieczności pociaga za sobą negatywizację samotności, ta zaś wydatnie wpływa na jednoznacznie dezaprobatywny jej odbiór. Tego rodzaju presumpcja, przyjmowana nie tylko jako biokulturowy standard, ale jako naukowy pewnik, ma niebagatelny wpływ na to, że kierując się nią, stajemy się w pewnej mierze ubezwłasnowolnieni, a prócz tego i w związku z tym w jakimś stopniu bezbronni wobec epizodów (a jeszcze bardziej wobec przedłużających się periodów) nawiedzającej nas - mimo społecznych zasieków - samotności. Spychana na margines życia społecznego samotność zwykle wkracza, nieproszona, w sam jego środek. Trenowane i nawykłe do ciagłej kohabitacji jednostki nie potrafią sobie mentalnie z tą sytuacją poradzić. Samotność jawi im się zrazu jako potworna niesprawiedliwość, gwałt zadany egzystencji, zaburzenie - mówiąc Leibnizem - wprzódy ustanowionego porządku; jako nieporównywalna z niczym egzystencjalna trauma; załamanie się tego, co przyswojone, znane i dzielone wspólnie z innymi; jako naznaczenie obciążającym i degradującym społecznie, a tym samym dehumanizującym stygmatem, którym opieczętowany - jak wyrokuje Arystoteles - ,jest jak ten kamień wyłączony w grze w kości”’69.

Wychowywanie i edukowanie w duchu dialektyki samotności i wspólnotowości mogłoby się znacznie przyczynić do uniknięcia lub osłabienia wielu tego rodzaju rozterek, kłopotów i dramatów, co oczywiście wcale nie znaczy, że zaradziłoby im lub zniosłoby je zupełnie. Mogłoby jednak uzdolnić poszczególne jednostki i całe społeczeństwa do rozumienia samotności jako integralnego i równoprawnego elementu życia, które na równi z integryzmem i aktywizmem społecznym tworzy człowieka, wpływa na jego los i stanowi o jakości jego życia oraz sposobie jego przeżywania. Trudno, w tym momencie, nie przywołać znamiennej i nader sugestywnej obserwacji Paula Tillicha, który w drugim tomie sławetnej Teologii systematycznej z 1957 roku, w części chrystologicznej, niedwuznacznie stwierdza:

Stan egzystencji jest stanem wyobcowania. [...] Wyobcowanie nie jest terminem biblijnym, lecz kryje się w większości biblijnych opisów ludzkiego predykamentu. Kryje się w symbolach wygnania z raju, we wrogości między człowiekiem a naturą, w morderczej wrogości brata wobec brata, w rozproszeniu narodów wskutek pomie-

${ }^{69}$ Zob. Arystoteles, Polityka z dodaniem Pseudo-Arystotelesowej ekonomiki, thum. L. Piotrowicz, Warszawa 1964, 1253a, 9, s. 6-7. 
szania języków oraz w ciąłych skargach proroków na ich królów i lud, który zwrócił się ku obcym bogom. Wyobcowanie kryje się w wypowiedzi Pawła, że człowiek przeinaczył przewrotnie obraz Boga w obraz bożków, w jego klasycznym opisie „człowieka, który się sobie sprzeniewierzył”, w jego wizji wrogości człowieka względem człowieka, idącej $\mathrm{w}$ parze $\mathrm{z}$ wypaczonymi pragnieniami. We wszystkich tych interpretacjach ludzkiego predykamentu jest implicite potwierdzany fakt wyobcowania. Nie jest więc z pewnością niczym niebiblijnym, jeśli opisując ludzką sytuację egzystencjalną, używamy terminu ,wyobcowanie”. [...] Predykamentem człowieka jest wyobcowanie, jego wyobcowanie zaś jest grzechem. Nie jest to stan rzeczy, jak choćby prawa natury, lecz sprawa zarówno osobistej wolności, jak i uniwersalnego przeznaczenia $^{70}$.

Tillich nie pozostawia wątpliwości co do tego, że wyobcowanie, które skazuje człowieka na samotność, jest czymś znacznie więcej niż epizodem, incydentem, interwałem, luką, szczeliną, rysą czy pęknięciem w obrębie ludzkiej egzystencji. Będące oznaką samotności wyobcowanie zostaje bowiem określone przezeń jako „predykament”, a więc kategorialny określnik, dystynktywna cecha, egzystencjalna determinanta. Nie istnieje ono, co prawda, na zasadzie prawa natury - powszechnie determinującej konieczności, czegoś w rodzaju fatum. Mimo to jednak wyobcowanie, a wraz z nim samotność, pozostają nieuniknione i niezbywalne jako rodzaj ,uniwersalnego przeznaczenia" ${ }^{\prime 1}$. Nie implikuje to jednak ich absolutności, wyrażającej się w braku przeciwieństwa oraz związanej z tym całkowitej nieprzezwyciężalności. Skoro wyobcowanie oznacza brak jedności i pozostawanie oddzielonym, odłączonym, odseparowanym od ,swego prawdziwego bytu"72, od tego, do czego esencjalnie należymy ${ }^{73}$, a ściślej - jak mówi Tillich - od „Boga, innych ludzi oraz samego siebie" do pomyślenia i zastosowania panaceum na wyobcowanie może być jego przeciwieństwo, zdolne ponownie zjednoczyć to, co rozdzielone, a mianowicie miłość wsparta religijną wiarą ${ }^{75}$.

Determinowanie ludzkich przekonań, postaw i zachowań monolektycznym wyobrażeniem kondycji ludzkiej, przesądzającym o jej wyłącznie społecznym charakterze i funkcji, przekłada się następnie na tworzenie i funkcjonowanie w społeczeństwie negatywnych stereotypów i wartościowań odnoszących się do samotności. Jeśli na ogół bezkrytycznie i powszechnie uznaje się, że uspołecznienie, towarzyskość czy wspólnotowość stanowią jedyną i wykładniczą normę,

${ }^{70}$ P. Tillich, Teologia systematyczna, t. 2, thum. J. Marzęcki, Kęty 2004, s. 48-49.

${ }^{71}$ Tamże, s. 49.

${ }^{72}$ Tamże, s. 48.

73 Tamże.

${ }^{74}$ Tamże, s. 49-50.

${ }^{75}$ Tamże, s. 50. Zagadnienie miłości jako przeciwieństwa i remedium na samotność dyskutuję osobno, wypunktowując i omawiając wątpliwości związane $\mathrm{z}$ tego rodzaju podejściem, w artykule: Miłość i samotność - konfrontacje, „Filozofia Chrześcijańska” t. 11, 2014, s. 43-68. 
określającą podstawowe dążenia i cele poszczególnych ludzi, nie powinno wówczas dziwić, że samotność - jako diametralne przeciwieństwo tamtych - równie bezkrytycznie i powszechnie postrzega się w kategoriach patologii, z którą za wszelką cenę i wszelkimi dostępnymi środkami należy walczyć. Tego rodzaju podejście i manifestującą się w nim strategię kulturową nazywam m o n ole k t y c z n y mi dla odróżnienia od podejścia i strategii dialektycznej. Monolektyczna hermeneutyka egzystencji, sprzymierzająca ją z paradygmatem, wyznaczającym kulturowy normatyw wspólnotowości, ryzykuje in effectu nierozumienie (respective nadinterpretację) i brak lub co najmniej obniżoną tolerancję na samotność u jej zwolenników, wyznawców i propagatorów. Prócz tego, może ona skutkować także wywoływaniem z góry i jednoznacznie negatywnych nastawień, generujących zawsze tylko pejoratywne osądy, w wyniku których tak przysposobiona jednostka na samą myśl o samotności reaguje podwyższonym lękiem, rozdrażnieniem i frustracją, odnosząc się do niej jak do czegoś ekstremalnie obcego, zgodnie z wyuczonym lub spontanicznie wytwarzanym schematem neutralizacji obcości. Podejście tego typu może się także przyczynić do osłabienia determinacji i obniżenia zdolności radzenia sobie z samotnością, powodując, że obiektywnie gorzej się ją znosi.

Przeciwko monolektycznej wykładni życia i powinności człowieka, zogniskowanych wokół płytko pojętego wymogu towarzyskości, wystąpił, między innymi - czyniąc to w sposób bezkompromisowy - Blaise Pascal. Swój sprzeciw najdobitniej wyraził słowami: „Nie ma dla człowieka nic równie nieznośnego, jak zażywać pełnego spoczynku, bez namiętności, bez spraw, rozrywek, zatrudnienia. Czuje wówczas swoją nicość, opuszczenie, niewystarczalność, zależność, niemoc, próżnię. Bezzwłocznie wyłoni się z głębi jego duszy nuda, melancholia, smutek, troska, żal, rozpacz" ${ }^{\prime 6}$. I dalej „,[...] Stąd pochodzi, iż gra i towarzystwo kobiet, wojna, wysokie urzędy są tak poszukiwane. [...] Stąd pochodzi, że ludzie tak miłują gwar i zgiełk; stąd pochodzi, iż więzienie jest tak straszną karą; stąd pochodzi, iż rozkosz samotności jest rzeczą niezrozumiałą"77.

W Pascalowskiej krytyce monolektycznego podejścia do wspólnotowości, której towarzyskość jest jednym z wyrazów, wybija się na czoło alternatywne wobec niego i paradoksalnie równie monolektyczne stanowisko, w którym wspólnotowość zostaje zastąpiona samotnością. Z uwagi jednak na ewidentną, nie tylko dla Pascala, aksjoformacyjną (formacja, kształcenie, wychowanie do preferencji dla wyższych wartości i wzniosłych scilicet co najmniej nieprzyziemnych zachowań) przewagę samotności nad motywacjami towarzyskimi monolektyczność tego ujęcia nie stanowi - przynajmniej dla jego eksponentów - takiego obciążenia, jak w odwrotnym przypadku, a nawet - rzec można - w porównaniu

${ }^{76}$ B. Pascal, Myśli, według układu L. Brunschvicga, tłum. T. Boy-Żeleński, Kraków 2003, pkt 131, s. 38

77 Tamże, pkt 139, s. 40. 
z tamtym okazuje się jego zaletą. Jeśli bowiem do stowarzyszania się z innymi pcha nas najsilniej obawa przed samotnością, wynikająca z nierozumienia jej, skorelowanego ponadto $\mathrm{z}$ nieumiejętnością wykorzystywania jej najpierw dla własnego, a później dla wspólnego pożytku, cóż więc pozytywnego można powiedzieć o tendencjach towarzyskich i wspólnototwórczych oraz ich rezultatach, skoro u samych ich podstaw tkwi negatywna motywacja i skłonności eskapistyczne, nie zaś autentyczne (respective szczere i nieprzymuszone) pragnienie towarzystwa czy wspólnoty.

\section{OD DIALEKTYKI SAMOTNOŚCI DO DIALEKTYCZNOŚCI ŻYCIA - SŁOWO PODSUMOWANIA}

Zygmunt Bauman przezornie wskazuje i podkreśla, że „Spór między bezpieczeństwem a wolnością, a więc spór między wspólnotą a indywidualnością, najprawdopodobniej toczyć się będzie jeszcze długo i nigdy chyba nie zostanie do końca rozwiązany" ${ }^{\prime 7}$. Niewykluczone - dodajmy od siebie - że cały ten spór to tylko pozór, gra interesów, ścieranie się rozmaitych przekonań, frakcji, stronnictw i praktyk. Co, jeśli dychotomia „samotność - wspólnotowość” ma raczej o n ty c zny niż de onty c zny charakter, jak się na ogół sądzi. Jeśli tak istotnie jest, musiałoby to z konieczności oznaczać, że niepotrzebnie wyostrzamy i radykalizujemy opozycje między samotnością respective indywidualnością a wspólnotowością, nakładając na to algorytm z góry określonych preferencji deontycznych. Postępując w ten sposób, siłą rzeczy prowokujemy spory. Poruszamy się bowiem w przestrzeni norm, a nie faktów, co niechybnie prowadzi do mniejszej lub większej arbitralności sądów. Jeśli prawdą jest, że dychotomia „samotność wspólnotowość" ma charakter ontyczny, wówczas wynika z tego, że są one (mianowicie samotność i wspólnotowość) elementami tego samego continuum - ludzkiej egzystencji, stanowiąc faktualne - zatem niezbywalne i niezaniedbywalne jej momenty. Tego rodzaju podejście zbliża nas do tezy o dialektyczności samej egzystencji, której samotność i wspólnotowość - aczkolwiek, rzecz jasna, nie tylko one - są, na zmianę, awersem i rewersem.

Jeśli jednak pozostaniemy w konwencji Arystotelesowskiej, decydując się na optykę monolektyczną (scilicet przeciwną dialektycznej), wówczas odpowiedź na wątpliwość Baumana, dotycząca perspektywy ostatecznego rozwikłania sporu między samotnością a wspólnotowością, będzie się tym bardziej domagała wejścia w perspektywę dialektyczną. Spór ten pozostanie nierozwiązany, jeśli samotność i wspólnotowość traktować się będzie jako zwalczające się opozycje. Owszem, są szanse na jego rozstrzygnięcie, pod warunkiem, że pójdziemy właśnie

${ }^{78}$ Z. Bauman, Wspólnota. W poszukiwaniu bezpieczeństwa $w$ niepewnym świecie, dz. cyt., s. $10-11$. 
drogą dialektyki samotności i wspólnotowości, do czego niniejszy tekst miał przekonać i zachęcić. Jak zaleca Seneka: „Najlepiej iść środkiem”79.

\section{BIBLIOGRAFIA}

Arystoteles, Polityka z dodaniem Pseudo-Arystotelesowej ekonomiki, tłum. L. Piotrowicz, Warszawa 1964.

Bauman Z., Wspólnota. W poszukiwaniu bezpieczeństwa w niepewnym świecie, thum. J. Margański, Kraków 2008.

Bierdiajew M., Rozważania o egzystencji. Filozofia samotności i wspólnoty, tłum. H. Paprocki, Kęty 2002.

Bowlby J., Attachement and Loss, vol. 1: Attachement, New York 1969, 1982.

Cutrona C., Transition to College. Loneliness and the Process of Social Adjustment, w: Loneliness. A Sourcebook of Current Theory, Research and Therapy, eds. L.A. Peplau, D. Perlman, New York 1982.

Czlowiek i pustka. Problemy wakuumologii, red. Z. Hull i W. Tulibacki, Olsztyn 2000.

Dołęa Z., Samotność młodzieży - analiza teoretyczna i studia empiryczne, Katowice 2003.

Domeracki P., Cierpienie w samotności - samotność w cierpieniu, w: Doświadczanie choroby w perspektywie badań interdyscyplinarnych, red. B. Płonka-Syroka i M. Skrzypek, Wrocław 2010, s. 199-208.

Domeracki P., Miłość i samotność - konfrontacje, „Filozofia Chrześcijańska” t. 11, 2014, s. 43-68.

Dubas E., Edukacja dorostych w sytuacji samotności i osamotnienia, Łódź 2000.

Dybeł K., Samotność w literaturze średniowiecznej Francji. Literatura narracyjna XII-XIII wieku, Kraków 2009.

Hrabal B., Zbyt głośna samotność, thum. P. Godlewski, Izabelin 2003.

Kant I., Idea powszechnej historii $w$ aspekcie kosmopolitycznym, thum. M. Żelazny, w: tenże, Rozprawy z filozofii historii, przekład zbiorowy, Kęty 2005.

Kant I., Metafizyczne podstawy nauki o cnocie, thum. W. Galewicz, Kęty 2005.

Kołakowski L., Mini wykłady o maxi sprawach, Kraków 2005.

McGraw J.G., Intimacy and Aloneness. A Multi-volume Study in Philosophical Psychology, v. 1: Intimacy and Isolation, Value Inquiry Book Series, v. 221, Amsterdam 2010.

McGraw J.G., Intimacy and Aloneness. A Multi-Volume Study in Philosophical Psychology, vol. 2: Personality Disorders and States of Aloneness, Amsterdam-New York 2012.

McGraw J.G., Samotność. Studium psychologiczne i filozoficzne, thum. A. Hankała, Warszawa 2000.

\footnotetext{
${ }^{79}$ L.A. Seneka, O pokoju ducha, dz. cyt., XVII 2, wyd. z 1963, s. 541.
} 
Mijuskovic B.L., Loneliness in Philosophy, Psychology, and Literature, Bloomington 2012.

Montaigne M. de, Próby, ks. 2, thum. T. Żeleński (Boy); oprac., wstępem i koment. opatrzył Z. Gierczyński; [cytaty łac. i grec. tłum. T. Sinko i E. Cięglewicz], Warszawa 1985.

Motywy samotności i wspólnoty $w$ dawnych literaturach romańskich (Średniowiecze Oświecenie), red. D. Szeliga i E.D. Żółkiewska, Warszawa 2010.

Pascal B., Myśli, według układu L. Brunschvicga, tłum. T. Boy-Żeleński, Kraków 2003.

Platon, Alkibiades I i inne dialogi oraz definicje, thum. L. Regner, Warszawa 1973.

Plessner H., Granice wspólnoty. Krytyka radykalizmu społecznego, thum. J. Merecki, Warszawa 2008.

Plessner H., Pytanie o conditio humana. Wybór pism, wybrał, oprac. i wstępem opatrzył Z. Krasnodębski, tłum. M. Łukasiewicz, Z. Krasnodębski, A. Załuska, Warszawa 1988.

Przeciw samotności, red. J. Twardowska-Rajewska, Poznań 2005.

Reale G., Historia filozofii starożytnej, t. 1, tłum. E.I. Zieliński, Lublin 1999.

Ricoeur P., Hermeneutyczna funkcja dystansu, w: tenże, Język, tekst, interpretacja. Wybór pism, thum. P. Graff i K. Rosner, Warszawa 1989.

Samotność i osamotnienie, „Horyzonty Wychowania” 11, 2012 (22), Akademia Ignatianum w Krakowie.

Seneka L.A., O gniewie, w: tenże, Dialogi, thum. L. Joachimowicz, Warszawa 1963.

Seneka L.A., O pokoju ducha, w: tenże, Dialogi, tłum. L. Joachimowicz, Warszawa 1989.

Singlizm. Nowy styl życia w ponowoczesnym świecie, red. K.L. Kuklińska, Warszawa 2013.

Smilansky S., 10 moralnych paradoksów, tłum. W. Kostrzewski, Kraków 2009.

Sobstyl K., Samotność i jej obrazy w języku, Lublin 2013.

Storr A., Samotnośćc: powrót do jaźni, thum. J. Prokopiuk i P.J. Sieradzan, Warszawa 2010.

Suchodolski B., Rozwój nowożytnej filozofii człowieka, Warszawa 1967.

Tillich P., Teologia systematyczna, t. 2, tłum. J. Marzęcki, Kęty 2004.

Tischner J., Filozofia dramatu. Wprowadzenie, Paris 1990.

Tischner J., Myślenie wedlug wartości, Kraków 1993.

Turkle S., Samotni razem. Dlaczego oczekujemy więcej od zdobyczy techniki, a mniej od siebie nawzajem, tłum. M. Cierpisz, Kraków 2013.

Wspólnota komunikacyjna w teorii i praktyce, red. B. Sierocka, Wrocław 2007.

Young J.E., Loneliness: Depression and Cognitive Therapy. Theory and Application, w: Loneliness. A Sourcebook of Current Theory, Research and Therapy, eds. L.A. Peplau, D. Perlman, New York 1982.

Zrozumieć samotność. Studium interdyscyplinarne, red. P. Domeracki i W. Tyburski, Toruń 2006. 


\section{SUMMARY}

The author of this paper is concentrated on a controversial and having not only one and satisfactory for different discussing it parts solution problem of the limits of the phenomena of loneliness and communitiveness. It is placed on a ground of the monoseological discourse as being intrinsic to it. The term 'monoseology' is derived from two combined ancient Greek words 'monosé', which means 'loneliness', and 'logos' - translated as 'science'. Hence monoseology, in its wider meaning, is used to designate all sciences interested in analyzing and conducting systematic research on loneliness; in a narrower sense the term 'monoseology' means simply just the philosophy of loneliness. It is quite commonly agreed that loneliness has only got bad sides in itself but communitiveness on the contrary has got only bright ones. Therefore loneliness deserves on clear and firm criticism while communitiveness is assessed in a univocally positive way. This, in turn, translates to an unquestionable preference to ideas, feelings, motives and acts which are of community character and use. On the other hand, loneliness is recognized as a reason of our pain, suffering, fears, sadness and horrible despair. It results that our key ambition, need and aim should be avoiding and preventing each form of loneliness in our private and social life at all costs. But, as it occurs, this causes a lot of further - not only theoretical but unfortunately also practical problems, which some researchers and ordinary people must face. This kind of unilateral and unambiguous interpretation both loneliness and communitiveness is called in the article "monolectical". In addition, it is shown in it that 'monolectics' of communitiveness or loneliness is insufficient for possibly objective and complete picture of this two. In consequence it is argued that monoseological discourse is able to gain it and to develop itself only by turning to the dialectical method of explaining. The fundamental thesis and belief as well, expressed on the ground of the dialectics of loneliness and communitiveness, is that loneliness and communitiveness are not at all isolated but strongly complementary. A practical conclusion arises from this statement according to which each of us should intertwine in his or her life some periods of communitiveness and then some periods of loneliness.

\section{Keywords}

communitiveness, loneliness, monoseology, philosophy of loneliness, monolectics, dialectics

\section{Słowa kluczowe}

wspólnotowość, samotność, monoseologia, filozofia samotności, monolektyka, dialektyka 